\title{
First implementation of the Large Fish Index (LFI) in the eastern Mediterranean
}

\author{
Dor Edelist ${ }^{1}$, Daniel Golani ${ }^{2}$, Ehud Spanier ${ }^{1}$ \\ ${ }^{1}$ Department of Maritime Civilizations and The Leon Recanati Institute for Maritime Studies, Charney School for Marine \\ Sciences, University of Haifa, Mount Carmel, Haifa 31905, Israel. E-mail: blackreefs@ gmail.com \\ ${ }^{2}$ Department of Evolution, Systematics and Ecology, the Hebrew University, Jerusalem 91904, Israel.
}

\begin{abstract}
Summary: The composition and structure of fish assemblages caught by trawl in the Levantine Sea (eastern Mediterranean) were summarized using a fishing-sensitive univariate indicator. This metric, called the 'Large Fish Index' (LFI), has been developed in the North Sea since 2000 and is applied and adapted here for the first time in the eastern Mediterranean. It was defined as the fish biomass fraction above a pre-determined length threshold, expressed as proportion of the total fish biomass. Trawl-caught assemblages in the warm, oligotrophic, highly invaded Levant were found to be characterized by small fishes. 'Large fish' were thus delineated as 20-30 cm (total length) for this region, as opposed to $40 \mathrm{~cm}$ set in the North Sea. Desired minimum LFI proportions were set as 0.5 for fishes longer than $20 \mathrm{~cm}$ and 0.3 for fishes longer than $30 \mathrm{~cm}$ and the actual values found in Israeli bottom trawl surveys from 2008 to 2012 were 0.3 and 0.155 respectively. These low LFI values for the small fishes caught by trawlers attest to the ecological unsustainability and economic inefficiency of bottom trawling in Israel and provide a tool for managers with which to assess the state of the fishery and the general health of the ecosystem.
\end{abstract}

Keywords: fish; overfishing; indicator; trawl; Mediterranean; Large Fish Index.

Primera aplicación del Índice de grandes peces (IGP) al Mediterráneo oriental

Resumen: La composición y estructura de las comunidades de peces capturados por arrastre en el mar de Levante (Mediterráneo Oriental) se expresó mediante un indicador univariado sensible a la pesca. Esta medida, denominada "Índice de grandes peces" (IGP), se desarrolló en el Mar del Norte desde 2000 y se aplica y se adapta por primera vez al Mediterráneo oriental. Se define como la fracción de biomasa de peces por encima de un umbral de longitud predeterminada, expresada como proporción de la biomasa total. Se encontró que los conjuntos de peces capturados en el mar de Levante, cálido, oligotrófico, y con muchas especies invasoras se caracterizan por estar formados de peces pequeños. Se definieron los "peces grandes" para esta región aquellos superiores a 20 o $30 \mathrm{~cm}$ de longitud total, en lugar de los $40 \mathrm{~cm}$ establecidos en el Mar del Norte. Las proporciones mínimas deseables de IGP se establecen en 0.5 para peces de más de $20 \mathrm{~cm}$ y 0.3 para los peces de más de $30 \mathrm{~cm}$ mientras que los valores reales que se encuentran en las campañas de arrastre de fondo israelíes $2008-2012$ fueron 0.3 y 0.155 , respectivamente. Estos bajos valores señalan la insostenibilidad ecológica y la ineficiencia económica de la pesca de arrastre en Israel y proporcionan una herramienta para los gestores con los que evaluar el estado de la pesca y la salud general del ecosistema.

Palabras clave: peces; sobrepesca; indicador; arrastre; Mediterráneo; índice de grandes peces.

Citation/Como citar este artículo: Edelist D., Golani D., Spanier E. 2014. First implementation of the Large Fish Index (LFI) in the eastern Mediterranean. Sci. Mar. 78(2): 185-192. doi: http://dx.doi.org/10.3989/scimar.scimar.03936.26A

Editor: J. Lleonart.

Received: August 15, 2013. Accepted: January 15, 2014. Published: May 26, 2014.

Copyright: () 2014 CSIC. This is an open-access article distributed under the Creative Commons Attribution-Non Commercial Lisence (by-nc) Spain 3.0.

\section{INTRODUCTION}

Addressing anthropogenically induced changes in fish communities through community-level or ecosystem-level indicators is imperative to the proper management of fisheries (Jennings 2005). In Mediter- ranean bottom trawling, this need is obviated by the multi-species nature of the fishery (Caddy et al. 1995) and the rapid biogeographic changes caused by Red Sea invasion that the local ichthyofauna is undergoing (Edelist et al. 2013). These render single-species indicators such as those proposed by Froese (2004) 
rather less practical and less indicative of the general state of the fishery or the ecosystem. Groundfish trawl surveys for assessing changes in various aspects of the community's composition, structure and function are widely used in the Mediterranean. They have provided us with much knowledge in recent years but their development and implementation as viable tools for fishery management still lag far behind those in northern European seas. Various metrics can be considered as tell-tale variables although few are as indicative and simple to understand as the Large Fish Index (LFI). This indicator is defined as the biomass fraction of fish above a pre-determined length threshold (i.e. "large" fish), expressed as a proportion of the total fish biomass (Heslenfeld and Enserink 2008, Greenstreet et al. 2011). This metric is sensitive to decreases in large fish biomass, which might be caused by overfishing, as well as to increases in small fish biomass caused by reduced predation by large fish (Fung et al. 2012). Therefore, the LFI responds to both the direct and indirect effects of fishing (Greenstreet et al. 2011). It has been adopted by the Oslo-Paris convention (OSPAR) as an indicator for fish community health as part of the Ecosystem Approach to Fisheries Management (Heslenfeld and Enserink 2008) and is listed as an indicator of "good environmental status" by the EU MSFD in descriptor 4 , under which member states are required to strive for good environmental status by the year 2020 (Fung et al. 2012). It has been successfully used in the North Sea (where it is most developed - see Greenstreet et al. 2011), the Celtic Sea (Shephard et al. 2011), the Baltic Sea and the Grand Banks (ICES 2011). As part of the EU MFSD the LFI was also very recently introduced in the western Mediterranean as part of the MEDITS surveys (Ordines et al. 2013). Here we wish to demonstrate the possible implementation of LFI in the eastern Mediterranean and discuss prerequisite adjustments mandated by the nature of trawl catches in the new and rapidly changing Levantine environment.

The Levantine Sea is a highly oligotrophic body of water, with high salinity and temperatures (e.g. Herut et al. 2000). These characteristics are perceived to be the main natural reason for the low fishery yields of the region (Caddy et al. 1995) and may also be associated with Levantine Nanism, characterized as "the smaller size and early maturation of several species in the Levant compared to conspecifics of the same sex and age in the northern and western Mediterranean" (Sonin et al. 2007). Mediterranean fish markets are thus culturally accustomed to and appreciative of smaller fishes, especially those harvested by the trawl fishery. This is accentuated in the Levant, where the main bottom trawl target species (e.g. goatfishes, pandoras, bogue) rarely attain sizes larger than $25 \mathrm{~cm}$ total length and are typically landed at only 10-15 cm (Appendix 1 . also see Edelist et al. 2011). The most striking phenomenon shaping species composition in the Levant is bioinvasion of tropical fauna through the Suez Canal and (Edelist et al. 2013), but its impacts on size spectra is yet unstudied. While smallness of the local fishes is a known fact, it is yet unknown whether it should be attributed solely to Levantine Nanism, or whether (and to what extent) excessive or unsustainable fishing is a contributing factor.

A sustainable fishery is expected to extract large animals, which have had time to reproduce and contribute to the gene pool (Pauly et al. 1998). Large fishes provide ecosystem services to humans (e.g. nutrition and employment), whereas small fish extraction represents economic wastage and inefficiency as well as an ecological crippling of future stocks. It therefore stands to reason that bottom trawling, long criticized for its low selectivity and extraction of small fish, is the chosen fishing method for implementation of the LFI. This is not the first time that trawling data have been proposed as an indicator for the state of fisheries in the Mediterranean. For example, the ratios of diversity and/or trophic level of the discarded and landed fractions of the catch were suggested by Tsagarakis et al. (2008) as such an indicator. Rochet and Trenkel (2003), however, found that multi-species indicators based on empirical population indicators (such as the LFI) were more reliable than indicators based on food web modelling. Moreover, the LFI itself can be highly indicative of trophic changes in demersal fish communities, since ontogenetic change and inter-specific variation in diet are strongly linked to predator body size (Greenstreet et al. 2010). The present study aims to demonstrate that the LFI can be implemented in the Levantine Sea, and describes how it can be tailored and adapted to the smaller size spectra of its fish.

\section{MATERIALS AND METHODS}

\section{Data collection}

Data were collected from 228 commercial trawl hauls using two-panel nets with sweeps (54-72 $\mathrm{m}$ between trawl doors) and a $40 \mathrm{~mm}$ PE diamond mesh at the codend. As these codends are considered highly non-selective and allow few fishes to escape (Sala et al. 2008), they sample the fish community with relatively little size-bias. Surveys were conducted monthly from November 2008 to June 2012 (detailed in Edelist et al. 2012a,b and Edelist 2013). Hauls were typically 3-5 h long, at a mean speed of $3 \mathrm{kn}$, and the 235-410 hp vessels produced a between trawl door opening of $55-75 \mathrm{~m}$. These surveys spanned the 173-km-long Israeli coast between latitudes $31^{\circ} 43 \mathrm{~N}$ and $33^{\circ} 05 \mathrm{~N}$, at depths of 15-240 m (Fig. 1). Surveys were performed year-round and seasons were defined as winter (JanMar), spring (Apr-Jun), summer (Jul-Sep) and autumn (Oct-Dec). A box of fish (5-12 kg) was extracted from each haul, and fishes were taxonomically identified to the species level and measured to the nearest $0.5-\mathrm{cm}$ interval. Specimens were later measured and weighed in the lab in order to find the respective length-weight relationships for the 101 commonest species (see Appendix 1). In instances where not enough specimens were weighed for a reliable length-weight assessment (usually due to scarcity of rarer species, accounting for less than $0.3 \%$ of the total biomass), weights were estimated based on length-weight relationships from the nearest location to the study site (Froese and Pauly 




Fig. 1. - Map of the study area and Israeli trawling grounds (adapted from Edelist et al. 2011).

2011). In Levantine trawling, specimens larger than 'a box of fish' are uncommon. The majority of such large fish are sharks or guitarfish, which are often discarded alive due to their low price (possibly this is related to religious preference due to their non-kosher status). Chondrichthyes, although measured and weighed, were thus later excluded from our LFI calculation. It is noteworthy, however, that particularly large and heavy fishes (mainly groupers and amberjacks) also affected the LFI strongly when included. In order to keep the overall picture conveyed to fishery managers clear and simple, here we adhered to the entire catch, excluding large Chondrichthyes (i.e. only bony fishes were included), which were later omitted from this analysis, as they are often discarded.

\section{Data analysis}

The length-weight relationships of fishes were used to allocate biomass to each measured specimen in samples. The LFI was then calculated sensu Greenstreet et al. (2010) as follows: First, the total biomass of fishes in all samples $(B)$ was calculated according to Equation 1:

$$
B=\sum_{s=1}^{S} \sum_{L=\min }^{l=\max } \sum_{n_{s, l}=1}^{N_{s, l}} C_{s} l^{b_{s}}
$$

where $S$ is the total number of species, $l$ is the length class and $N_{s, l}$ is the total number of individuals in each length class of each species. The $c_{s}$ and $b_{s}$ values are the constant and exponent, respectively, in the speciesspecific weight-at-length relationship (appearing as ' $a$ ' and ' $b$ ' respectively in Appendix 1). The LFI was then calculated in Equation 2 (below) by summing the biomass exceeding every size group (i.e. the $W$ exceeding every $l$ ) by the total biomass $(B)$ from Equation 1 as follows:

$$
\mathrm{LFI}=\frac{\sum_{s=1}^{S} \sum_{l>40 \mathrm{~cm}}^{l=\max } \sum_{n_{s, l}=1}^{N_{s, l}} w_{s, l}}{B}
$$

Note that in the numerator for this equation, the summation is carried out across $l>40 \mathrm{~cm}$ only (i.e. the North Sea LFI value) while here we proceeded to calculate it for the entire size spectrum.

Mediterranean trawl fisheries target much smaller finfish than Atlantic European fleets (Caddy 2009) and these essentially juvenile populations are much more susceptible to inter-annual variations in recruitment and in natural mortality (they cannot be assumed to have constant natural mortality). This obviates the need for indicators that will be both sensitive to fishing mortality (larger fish sizes, here we chose $30 \mathrm{~cm}$ ) and suited to the small size of most target species (i.e. 20 $\mathrm{cm}$ ) and we focus on these values in our analysis.

\section{RESULTS}

Our 2008-2012 surveys yielded 72812 bony fish length measurements, out of which 70461 (96.7\%) were below $20 \mathrm{~cm}$, and 72150 (99\%) were below 30 $\mathrm{cm}$. In the North Sea, Greenstreet et al. (2011) for example, found that $95 \%$ of the trawled fish (by number) were shorter than $30 \mathrm{~cm}$, underscoring the lack of large fishes in the Levantine assemblage. The $\mathrm{LFI}_{20}$ and $\mathrm{LFI}_{30}$ values were 0.3 and 0.15 respectively (Fig. 2), meaning that $70 \%$ and $85 \%$ of the fished biomass originates in fishes smaller than $20 \mathrm{~cm}$ and $30 \mathrm{~cm}$, respectively.

As Mediterranean trawlers rely more on juvenile fishes than Atlantic ones (Caddy 2009), the Mediterranean catch composition is expected to depend greatly on seasonality. This is, indeed, echoed in our results, as LFI values declined during the summer recruitment 


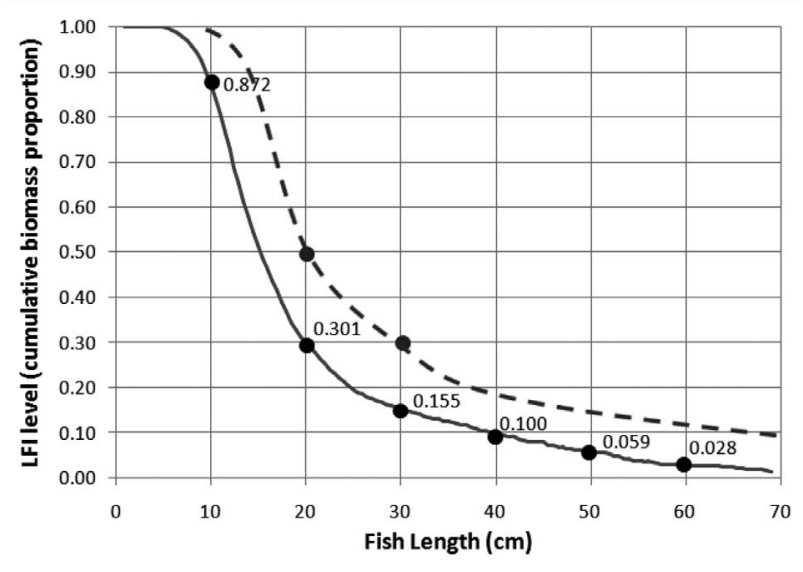

Fig. 2. - The LFI curve for the 2008-2012 surveys. Black dots mark LFI levels at 10-60 cm, and a theoretical catch curve, passing through the desired $\mathrm{LFI}_{20}=0.5$ and $\mathrm{LFI}_{30}=0.3$ values (dashed line).

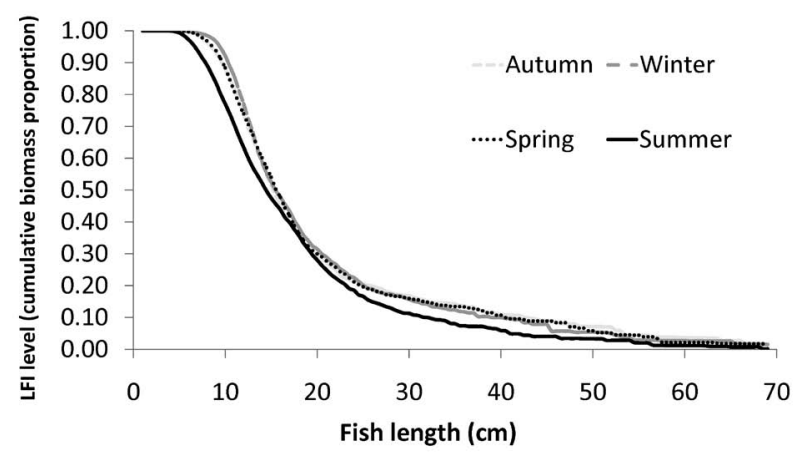

Fig. 3. - LFI curves for the 2008-12 trawler catch in winter (JanMar), spring (Apr-Jun), summer (Jul-Sep) and autumn (Oct-Dec).

season by $0.05-0.2$ (Fig. 3). This analysis was unavailable when the LFI was applied to data obtained from the $20 \mathrm{~mm}$ mesh MEDITS surveys, in which the annual analysis was the main application allocated to the LFI within the EU MSFD for the Mediterranean (Ordines et al. 2013).

We also calculated the LFI separately for each year (Fig. 4). While LFI values seem to have improved over the study period, the low values for 2008 and high values for 2012 are a function of the seasonal variance in sampling and thus reflect seasonal rather than annual trends.

The 'smallness' of Levantine fish assemblages may also be rooted in invasive species. Of the 72812 fishes measured in this study, 56307 (58.4\%) were Lessepsian Migrants-Nonindigenous fishes of Indo-Pacific origin. The three most common species in this study, accounting together for $30 \%$ of the specimens, were nonindigenous: 1) The tiny (typically $5-10 \mathrm{~cm}$ total length) pony fish Equulites klunzingeri, which almost creates its own new size class in the Mediterranean (Fig. 5); 2) The commercially important goatfish $U p$ eneus moluccensis, rather smaller than its displaced indigenous confamilials, Mullus barbatus and M. surmuletus; 3) The venomous catfish Plotosus lineatus, which exploded in population (Edelist et al. 2012a) since its recent introduction a decade ago. While not

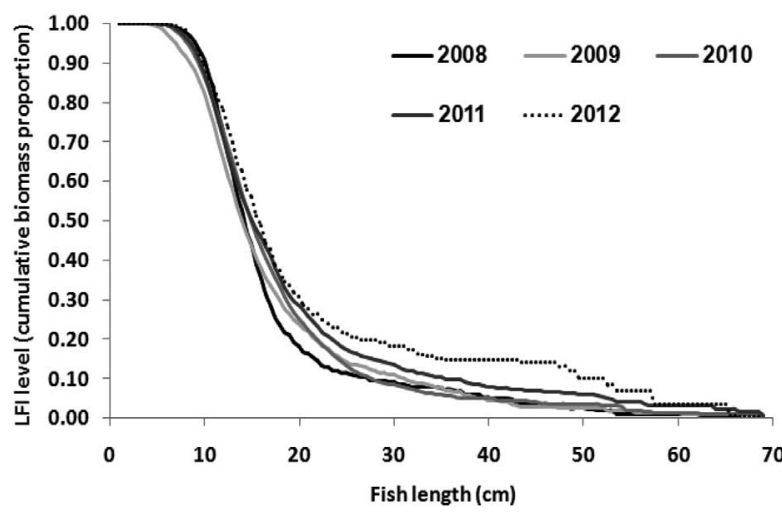

Fig. 4. - Annual LFI curves for the years 2008-2012. Note that surveys began in the autumn of 2008 and ended in the spring of 2012.

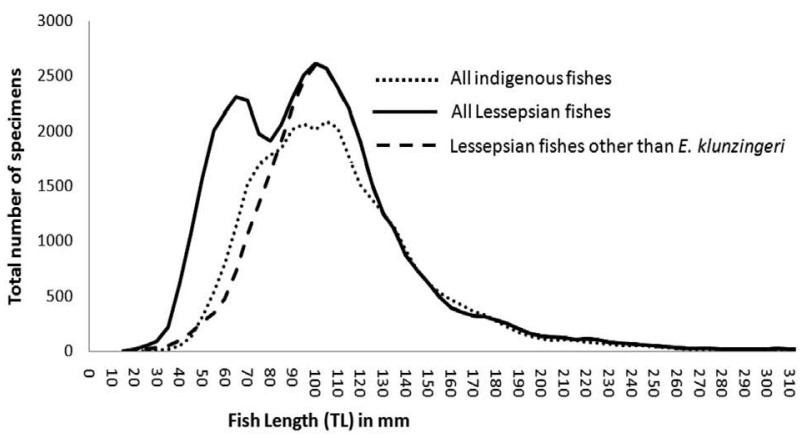

Fig. 5. - Size composition (Two point moving average on the $\mathrm{x}$ axis) of all 72812 fishes caught in the present study, with special reference to the small non-indigenous ponyfish Equulites klunzingeri.

nearly as short as the ponyfish (with $\mathrm{L}_{\max }$ of $>20 \mathrm{~cm}$ ), the slender catfish is very light compared to its length, and considerably negatively impacts the LFI. Unlike the goatfish, which is only discarded when smaller than $8-9 \mathrm{~cm}$, the ponyfish and the catfish are wholly discarded.

In sizes of $12.5-18 \mathrm{~cm}$, indigenous species slightly outnumber nonindigenous ones, but many indigenous species are also by-caught in small sizes of 5-10 cm total length (Fig. 3). These are mainly juvenile porgies (Pagellus spp.), goatfishes (Mullus spp.) and Bogue (Boops boops), extracted in large abundance every spring and summer during their recruitment.

\section{DISCUSSION}

In Figure 2 we present (dashed line) a more sustainable LFI contour based on the arbitrarily set values of $\mathrm{LFI}_{20}=0.5$ and $\mathrm{LFI}_{30}=0.3$, which we consider as reasonable for the Levant. These values are higher than the actual values by about the same proportion as target LFI values of the North Sea are higher than actual values (i.e. the target values are 1.5-2 times the actual values, see Greenstreet et al. 2011 and Fung et al. 2012). We propose them as indicative reference points that represent a healthy Levantine trawl fishery. Fishes 20 to $30 \mathrm{~cm}$ long thus abound in the Mediterranean in the same range of LFI values as 40-cm-long 
fishes do in the North Sea. We therefore suggest that considering the smallness of the Levantine species assemblage, 0.5 for $20 \mathrm{~cm}$ and 0.3 for $30 \mathrm{~cm}$ can similarly be considered as benign levels for this region. The $40 \mathrm{~cm}$ value proposed for the North Sea was set to maximize the LFI sensitivity to fishing pressure rather than to recruitment events and other ex-fishery factors (Greenstreet et al. 2011). The recruitment of (mainly indigenous) Mediterranean species occurs in the summer, following spawning (Edelist et al. 2011, 2012b). This is when juveniles reach sizes large enough (typically $5-13 \mathrm{~cm}$ ) to be caught in the $\sim 40 \mathrm{~mm}$ diamond mesh nets dragged by the Israeli trawl fleet.

\section{Ex-fishery factors contributing to small sizes in Levantine fishes}

Rochet et al. (2010) propose that an exploited groundfish community can be viewed as a three-level food chain with two upper levels that are target catch, while the lower level is subject mostly to environmental variation. Metrics relying on the lower level are therefore often criticized for their dependence on natural events (Rochet et al. 2010). However, the LFI was found to be comparably robust to such perturbations (Greenstreet et al. 2011, ICES 2011) as biomass is less sensitive to changes in the lower level components of the catch. The fish assemblage of the eastern Mediterranean is 'naturally' small, but there is another way in which it varies significantly from that of the western Mediterranean.

The faunistic invasion via the Suez Canal has profoundly and irreversibly altered the composition of the Levantine ichthyofauna (Edelist et al. 2013). Indigenous species now occupy ever deeper strata, as they are being displaced by Indo-Pacific species along bathymetric axes and fishwise, Levantine shallows are now almost tropical. For example, Edelist et al. (2013) have shown that nonindigenous fish accounted for $84 \%$ of the abundance and $66 \%$ of the biomass in waters shallower than $30 \mathrm{~m}$ in Israel. The difference between these percentages alludes to the small body size of migrants and also coincides with the upper, warmest layer in the water column. Surely the long-term impacts of this unidirectional process must be weighed carefully upon analysis of the LFI indicator.

One main natural cause in explaining overall diminished sizes in Levantine fishes is undoubtedly Bergmann's rule, stating that within a broadly distributed species, specimens from cooler climates tend to be larger than conspecifics from warmer climates (Bergmann 1847). The waters of the eastern Mediterranean are warmer by $\sim 6-9^{\circ} \mathrm{C}$ than those of the western basin (Nykjaer 2009) and Levantine fishes are thus expected to be smaller not only than those from the North Sea, but also than those from the western Mediterranean. Another reason for this lies in the extreme natural oligotrophy of the region, previously suggested as the main reason for Levantine Nanism (Sonin et al. 2007). This is possibly exacerbated by damming of the Nile River in Aswan in 1964, which curtailed the annual flooding of this once giant river, cut its freshwater flow to less than $10 \%$ of previous levels, and eliminated phytoplankton blooms associated with the nutrients swept into the Mediterranean by floods (Oczkowski et al. 2009). Here we propose that a third factor is contributing to the small size of the assemblage - the influx of nonindigenous Indo-Pacific species through the Suez Canal.

\section{The need to allocate a proper species complex for Levantine LFI}

The 0.3 LFI level was proposed for the North Sea (using the $40 \mathrm{~cm}$ length) to denote 1983 levels. The actual values declined to a low of 0.05 in 2001, and recovered to 0.22 in 2008 (Greenstreet et al. 2011). This finding has been recently disputed by Fung et al. (2012), who showed stable values of 0.1 to 0.15 in recent years, and this correction was later acknowledged by Greenstreet et al. (2012). These difficulties have arisen predominately from recent inclusion of different areas, not counted in earlier years, which skewed the impact of certain important species (particularly cod) in the complex. While fishing areas are not a decisive issue in the small Israeli fishery, choosing which species to include in the index is of paramount importance. The allocation of an appropriate species complex per region of study is critical to calculating the LFI (ICES 2011); and in the fast changing multi-species catch of the Israeli trawl fishery (Edelist et al. 2011, 2013) such deliberations are likely to turn into an ongoing discussion. The decision to exclude Chondrichthyes while including groupers and amberjacks is a useful example of such an adaptation.

\section{Levantine size spectra and adjustment of the LFI}

The LFI was created to serve as an indicator of the "general health" of the demersal fish community. Its strengths lie in its simplicity, wide acceptance and sensitivity to fishing pressure (Greenstreet et al. 2011). In the North Sea, it was chosen ahead of alternative metrics such as abundance, biomass, productivity, species richness, species diversity and mean life-history trait composition because it was found to be particularly sensitive to variation in fishing pressure. Therefore it directly reflects the effect of fishing on the state of the fish community (Shephard et al. 2011). We suggest that it can be applied in the Levant if the target levels are carefully adjusted to its unique, small bodied species assemblage.

\section{Annual LFI measurements}

We do not yet know how long it would take the Levantine fishery to respond to anomalous year classes, recruitment events or even fishery management measures, as the general state of knowledge of Levantine fisheries lags considerably behind that of the North Sea. Without this knowledge we forewarn against jumping to distracting and possibly misleading conclusions due to exceedingly high or low single-year values. This must also be taken into consideration during survey de- 
sign, so that variables affecting size spectra are equally sampled. For example, in our study the low values in 2008 and high values in 2012 (Fig. 4) stemmed from partial seasonal coverage rather than annual variation, underlining the importance of sampling whole years.

\section{Limitations and applications of the LFI}

There are several obvious drawbacks of the LFI in its current form. First, invertebrates and especially shrimps and squids, which comprise a significant part of the catch of Israeli bottom trawlers, are excluded. Second, The $\mathrm{LFI}_{30}$ is insensitive to changes in the size classes of some of the commonest commercial species such as goatfishes or the smaller sparids, which have an $\mathrm{L}_{\max }$ smaller than $30 \mathrm{~cm}$. The $\mathrm{LFI}_{20}$, however, makes the index more prone to recruitment class strength. Third, because samples rather than the entire catch were used the impact of larger and heavier specimens, caught much more sporadically than smaller-bodied species, was considerable. For example, the omission of sharks and guitarfish from the analysis decreased LFI values by $0.05-0.1$, underlining the importance of proper species complex allocation. Finally, the inclusion of both by-caught species and target species in the catch means that large by-caught species regularly exceeding $30 \mathrm{~cm}$ (like the poisonous puffer Lagocephalus sceleratus), contribute heavily to the index. At the same time, smaller high value species such as goatfishes, which hardly reach $20 \mathrm{~cm}$ as adults, have a lower weight in the index (Edelist 2013).

Despite these shortcomings, we maintain that the proposed LFI indicator can serve particularly well for several purposes. First, fishery managers, scientists and the public can be alerted to the unsustainable nature of trawling in the Levant today and the small size of the exploited assemblage with a simple to understand index. Second, the seasonal evolution of the LFI also allows makes it possible to detect when the fishery produces the largest juvenile proportion in the catch. The wastage incurred by fishing in the summer is well reflected in Figure 2. Trawlers fish year-round in Israel and there is unfortunately no summer moratorium on fishing as in other Mediterranean countries (Edelist et al. 2011 and references therein). The LFI can thus be used to evaluate the efficacy of management measures such as seasonal moratoria. Thrid, the LFI can be used to assess the response strength and lag-times for the trawled Levantine assemblage, and to further refine the index itself.

\section{CONCLUSIONS}

The LFI can be applied in the Mediterranean and is presented here as a useful tool for examining the sustainability of bottom trawling in Israel. Even taking into consideration the smallness of Levantine ichthyofauna, the environmental performance of Israeli trawlers still seems rather poor, with fishes larger than $30 \mathrm{~cm}$ only accounting for $15 \%$ of the fish biomass. We therefore encourage managers to use measures such as seasonal closures, MPAs or gear changes in order to increase trawl selectivity. Also, we suggest that the arbitrary values set here as characterizing "Good Environmental Status" are revisited and discussed further if and when such measures are used. As advised for northern European seas (Greenstreet et al. 2011, ICES 2011), we propose that the LFI should be used in conjunction with other metrics. This is imperative in order to facilitate a more complete assessment of ecosystem response to variations in fishing pressure and to other stressors, such as marine invasion, which profoundly shapes the region's ichthyofauna. Finally, a wide-scale, long-term application of the LFI and its implementation in other Mediterranean fisheries can serve to further improve, calibrate and standardize the index, which can serve to further improve, calibrate and standardize the index, towards a better understanding of the impacts of fishing on Mediterranean stocks.

\section{ACKNOWLEDGEMENTS}

This study was supported by a research grant from the Israeli Ministry of Environmental Defense. The authors also wish to thank Dr. Jason Goldstein for the useful suggestions which have led to significant improvements of this manuscript.

\section{REFERENCES}

Bergmann C. 1847. Ueber die verhältnisse der wärmeökonomie der thiere zu ihrer grösse. Gottinger. studien. 3: 595-708

Caddy J.F., Refk R., Do-Chi T. 1995. Productivity estimates for the Mediterranean: evidence of accelerating ecological change. Ocean. Coast. Manage. 26: 1-18. http://dx.doi.org/10.1016/0964-5691(95)00015-T

Caddy J.F. 2009. Practical issues in choosing a framework for resource assessment and management of Mediterranean and Black Sea fisheries. Med. Mar. Sci. 10(1): 83-119.

Edelist D. 2013. New length-weight relationships and Lmax values for fishes from the Southeastern Mediterranean Sea. J. App. Icht. 30: 521-526. http://dx.doi.org/10.1111/j.1439-0426.2012.02060.x

Edelist D., Sonin O., Golani D., et al. 2011. Spatiotemporal patterns of catch and discards of the Israeli Mediterranean trawl fishery in the early 1990s: ecological and conservation perspectives. Sci. Mar. 75(4): 641-652 http://dx.doi.org/10.3989/scimar.2011.75n4641

Edelist D., Golani D., Rilov G., et al. 2012a. Population explosion of invasive venomous striped eel catfish Plotosus lineatus in the Levant: possible mechanisms. Mar. Biol. 159(2): 283-290. http://dx doi.org/10.1007/s00227-011-1806-4

Edelist D., Golani D., Spanier E. 2012b. Ecological indicators for overfishing in Israel's trawl fishery. Tech. rep. submit. Israel Ministry Environm. Protect. 50 pp. (in Hebrew).

Edelist D., Rilov G., Golani D., et al. 2013. Restructuring the sea: Profound shifts in the world's most invaded marine ecosystem. Divers. Distrib. 19: 69-77. http://dx.doi.org/10.1111/ddi.12002

Froese R. 2004. Keep it simple: three indicators to deal with overfishing. Fish. Fisheries 5: 86-91. http://dx.doi.org/10.1111/j.1467-2979.2004.00144.x

Froese R., Pauly D. (eds). 2011. FishBase. World Wide Web electronic publication. www.fishbase.org

Fung T., Farnsworth K.D., Reid D.G., et al. 2012. Recent data suggest no further recovery in North Sea Large Fish Indicator. ICES J. Mar. Sci. 69: 235-239. http://dx.doi.org/10.1093/icesjms/fsr206

Greenstreet S.P R, Fraser H.M., Cotter J., et al. 2010. Assessment of the "State" of the Demersal Fish Communities in UK waters. Technical background paper: Biodiversity and Ecosystem Services 1(3): $34 \mathrm{pp}$.

Greenstreet S.P.R., Rogers S.I., Rice J.C., et al. 2011. Development of the EcoQO for the North Sea fish community. ICES. J. Mar. 
Sci. 68: 1-11.

http://dx.doi.org/10.1093/icesjms/fsq156

Greenstreet S.P.R., Rogers S.I., Rice J.C., et al. 2012. A reassessment of trends in the North Sea Large Fish Indicator and a re-evaluation of earlier conclusions. ICES. J. Mar. Sci. 69: 343-345. http://dx.doi.org/10.1093/icesjms/fsr201

Herut B., Almogi-Labin A., Jannink N., et al. 2000. The seasonal dynamics of nutrient and chlorophyll a concentrations on the SE Mediterranean shelf-slope. Oceanol. Acta. 23: 771-782. http://dx.doi.org/10.1016/S0399-1784(00)01118-X

Heslenfeld P., Enserink E.L. 2008. OSPAR Ecological Quality Objectives: the utility of health indicators for the North Sea. ICES. J. Mar. Sci. 65: 1392-1397. http://dx.doi.org/10.1093/icesjms/fsn159

ICES. 2011. Report of the Working Group on the Ecosystem Effects of Fishing Activities (WGECO), 13-20 April, Copenhagen, Denmark. ICES CM 2011/ACOM 24, 166 pp.

Jennings S. 2005. Indicators to support an ecosystem approach to fisheries. Fish. Fisheries. 6(3): 212-232. http://dx.doi.org/10.1111/j.1467-2979.2005.00189.x

Nykjaer L. 2009. Mediterranean Sea surface warming 1985-2006. Clim. Res. 39: 11-17. http://dx.doi.org/10.3354/cr00794

Oczkowski J.A., Nixon S.W., Granger S.L., et al. 2009. Anthropogenic enhancement of Egypt's Mediterranean fishery. P. Natl. Acad. Sci. 106(5): 1364-1367. http://dx.doi.org/10.1073/pnas.0812568106

Ordines F., Quetglas A., Massutí E., et al. 2013. Estrategia marina demarcacion marina Levantino-Balear Parte IV. Descriptores buen estado ambiental. Descriptor 4: Redes troficas evaluacion inicial y buen estado ambiental. Available online at: http://www.magrama.gob.es/es/costas/temas/estrategias-marinas/IV D4 Levantino Balear tcm7-207257.pdf

Pauly D., Christensen V., Dalsgaard J., et al. 1998. Fishing down marine food webs. Science. 279(5352): 860-863. http://dx.doi.org/10.1126/science. 279.5352 .860

Rochet M.J., Trenkel V.M. 2003. Which community indicators can measure the impact of fishing? A review and proposals. Can. J. Fis. Aquat. Sci. 60: 86-99. http://dx.doi.org/10.1139/f02-164

Rochet M.J., Trenkel V.M., Carpentier A., et al. 2010. Do changes in environmental pressures impact marine communities? An empirical assessment. J. App. Ecol. 47: 741-750. http://dx.doi.org/10.1111/j.1365-2664.2010.01841.x

Sala A., Lucchetti A., Piccinetti C., et al. 2008. Size selection by diamond and square-mesh codends in multi-species Mediterranean demersal trawl fisheries. Fish. Res. 93(1-2): 8-21. http://dx.doi.org/10.1016/j.fishres.2008.02.003

Shephard S., Reid D.G., Greenstreet S.P.R. 2011. Interpreting the large fish indicator for the Celtic Sea. ICES. J. Mar. Sci. 68: 1963-1972. http://dx.doi.org/10.1093/icesjms/fsr114

Sonin O., Spanier E., Levi D., et al. 2007. Nanism (dwarfism) in fish: a comparison between red mullet Mullus barbatus from the southeastern and the central Mediterranean. Mar. Ecol. Prog. Ser 343: 221-228 http://dx.doi.org/10.3354/meps06917

Tsagarakis, K., Machias A., Giannoulaki M., et al. 2008. Seasonal and temporal trends in metrics of fish community for ottertrawl discards in a Mediterranean ecosystem. ICES. J. Mar. Sci. 65(4): 539-550.

http://dx.doi.org/10.1093/icesjms/fsn023

Appendix 1. - Length-weight parameters (a,b); standard error [SE(b)]; $\mathrm{R}^{2}$; number of weighed specimens (n); minimum (Min) and maximum (Max) sizes found for the 101 commonest bony fish species (out of 146 total) caught in Israel by bottom trawl during the $2008-12$ campaign. Lessepsian migrants are marked by $*$.

\begin{tabular}{|c|c|c|c|c|c|c|c|}
\hline Species & $\mathrm{a}$ & $\mathrm{b}$ & $\mathrm{SE}(\mathrm{b})$ & $\mathrm{R}^{2}$ & $\mathrm{n}$ & Min & $\operatorname{Max}$ \\
\hline Alectis alexandrinus & 0.0398 & 2.6263 & 0.027399 & 0.9949 & 3 & 7.5 & 33.5 \\
\hline Alepes djedaba* & 0.011 & 2.972 & 0.007174 & 0.9899 & 43 & 3.5 & 23 \\
\hline Apogon imberbis & 0.0161 & 2.9869 & 0.005903 & 0.9659 & 30 & 6.6 & 10.5 \\
\hline Apogonichthyoides pharonis* & 0.017 & 3.1274 & 0.015471 & 0.9577 & 21 & 4 & 9.5 \\
\hline Argentina sphyraena & 0.0007 & 3.8389 & 0.011064 & 0.9776 & 10 & 9.4 & 13.5 \\
\hline Ariosoma balearicum & 0.0019 & 2.894 & 0.009562 & 0.9059 & 34 & 10.5 & 25 \\
\hline Arnoglossus sp. & 0.0087 & 3.0721 & 0.011529 & 0.9022 & 68 & 4.5 & 11.2 \\
\hline Atherinomorus forskali & 0.0125 & 2.8666 & 0.03419 & 0.77 & 11 & 8 & 11.9 \\
\hline Balistes carolinensis & 0.0756 & 2.546 & 0.00942 & 0.981 & 33 & 15 & 66 \\
\hline Boops boops & 0.011 & 2.9293 & 0.009304 & 0.9502 & 170 & 5 & 24 \\
\hline Bothus podas & 0.0106 & 3.0636 & 0.008272 & 0.9535 & 92 & 6 & 16.3 \\
\hline Bregmasceros atlanticus & 0.0301 & 2.183 & 0.021361 & 0.8173 & 12 & 5.2 & 7.5 \\
\hline Callionymus filamentosus* & 0.0284 & 2.4409 & 0.006075 & 0.8306 & 199 & 6 & 15.5 \\
\hline Capros aper & 0.0255 & 2.8223 & 0.023148 & 0.8649 & 14 & 2 & 10.5 \\
\hline Caranx crysos & 0.0089 & 3.108 & 0.009288 & 0.9843 & 30 & 11.7 & 54 \\
\hline Chlorophthalmus agassizii & 0.0065 & 3.0486 & 0.01641 & 0.909 & 78 & 4 & 12.5 \\
\hline Citharus linguatula & 0.0071 & 3.021 & 0.011477 & 0.95 & 92 & 5.5 & 21 \\
\hline Conger conger & 0.0011 & 3.0663 & 0.006989 & 0.9731 & 59 & 17 & 83 \\
\hline Cynoglossus sinusarabici* & 0.0167 & 2.7044 & 0.007824 & 0.9683 & 37 & 6 & 16 \\
\hline Decapterus russelli* & 0.0051 & 3.2185 & 0.006917 & 0.9855 & 70 & 6 & 21 \\
\hline Dentex macrophthalmus & 0.011 & 3.1353 & 0.004401 & 0.9522 & 57 & 9 & 14.5 \\
\hline Diplodus annularis & 0.0242 & 2.8583 & 0.012587 & 0.9475 & 9 & 9 & 13.5 \\
\hline Diplodus cervinus & 0.014 & 3.023 & 0.009064 & 0.967 & 12 & 18 & 35 \\
\hline Diplodus puntazzo & 0.0257 & 2.8483 & 0.007489 & 0.9448 & 11 & 15.5 & 22 \\
\hline Diplodus sargus & 0.0171 & 3.0011 & 0.004452 & 0.9816 & 30 & 14 & 25.5 \\
\hline Diplodus vulgaris & 0.0139 & 3.0335 & 0.004616 & 0.9508 & 32 & 12.5 & 24 \\
\hline Dussumieria elopsoides* & 0.0053 & 3.1562 & 0.006841 & 0.976 & 37 & 8.2 & 14.5 \\
\hline Echelus myrus & 0.0001 & 3.4528 & 0.006842 & 0.9555 & 36 & 34.4 & 74.5 \\
\hline Echeneis naucrates & 0.0006 & 3.417 & 0.012928 & 0.9921 & 9 & 17.5 & 63.5 \\
\hline Engraulis encrasicolus & 0.0081 & 2.9224 & 0.006573 & 0.9764 & 38 & 6 & 15 \\
\hline Epinephelus aeneus & 0.013 & 2.958 & 0.006521 & 0.996 & 34 & 8.5 & 85 \\
\hline Equulites klunzingeri* & 0.0086 & 3.1726 & 0.009908 & 0.9252 & 134 & 3.5 & 10.1 \\
\hline Etrumeus golani $*$ & 0.0088 & 2.9832 & 0.012074 & 0.9731 & 16 & 8 & 24 \\
\hline Euthynnus alletteratus & 0.008 & 3.074 & 0.012671 & 0.993 & 10 & 31.5 & 97 \\
\hline Fistularia commersonii* & 0.0001 & 3.3501 & 0.011223 & 0.983 & 40 & 13 & 99.5 \\
\hline Gobius niger & 0.0073 & 3.1241 & 0.023896 & 0.9704 & 7 & 5.5 & 12.5 \\
\hline Helicolenus dactylopterus & 0.0166 & 2.9725 & 0.005856 & 0.9896 & 52 & 6 & 16 \\
\hline Jaydia fasciatus* & 0.014 & 3.1609 & 0.009218 & 0.9403 & 42 & 5.5 & 9.5 \\
\hline
\end{tabular}


Appendix 1 (cont.). - Length-weight parameters (a,b); standard error [SE(b)]; $\mathrm{R}^{2}$; number of weighed specimens (n); minimum (Min) and maximum (Max) sizes found for the 101 commonest bony fish species (out of 146 total) caught in Israel by bottom trawl during the $2008-12$ campaign. Lessepsian migrants are marked by *.

\begin{tabular}{|c|c|c|c|c|c|c|c|}
\hline Species & $\mathrm{a}$ & $\mathrm{b}$ & $\mathrm{SE}(\mathrm{b})$ & $\mathrm{R}^{2}$ & $\mathrm{n}$ & Min & Max \\
\hline Jaydia smithi* & 0.0161 & 2.9546 & 0.006961 & 0.9829 & 145 & 3.4 & 14.5 \\
\hline Lagocephalus sceleratus* & 0.0225 & 2.8227 & 0.00821 & 0.9907 & 57 & 5 & 56.5 \\
\hline Lagocephalus spadiceus* & 0.0243 & 2.8686 & 0.005618 & 0.9906 & 103 & 5.5 & 42 \\
\hline Lagocephalus suezensis* & 0.012 & 2.999 & 0.003894 & 0.9684 & 128 & 6 & 19.5 \\
\hline Lepidopus caudatus & 0.00005 & 3.7074 & 0.026623 & 0.9966 & 6 & 25 & 51.5 \\
\hline Lepidotrigla cavillone & 0.0057 & 3.3492 & 0.009555 & 0.9412 & 121 & 4.5 & 12.5 \\
\hline Lepidotrigla dieuzeidei & 0.0137 & 2.9418 & 0.012391 & 0.9504 & 6 & 9 & 11.5 \\
\hline Lithognathus mormyrus & 0.0121 & 3.0175 & 0.004074 & 0.9852 & 86 & 7 & 25 \\
\hline Lophius budegassa & 0.0049 & 3.264 & 0.017153 & 0.9908 & 5 & 21 & 61 \\
\hline Macrorhamphosus scolopax & 0.008 & 2.8543 & 0.011771 & 0.9501 & 57 & 4 & 12 \\
\hline Merluccius merluccius & 0.0035 & 3.233 & 0.005637 & 0.989 & 74 & 7.5 & 37 \\
\hline Microchirus ocellatus & 0.0792 & 2.312 & 0.000785 & 0.8952 & 12 & 7 & 13 \\
\hline Mullus barbatus & 0.0107 & 3.0012 & 0.007972 & 0.9686 & 182 & 5 & 22 \\
\hline Mullus surmuletus & 0.0054 & 3.2824 & 0.003276 & 0.9827 & 167 & 7.5 & 23 \\
\hline Nemipterus randalli* & 0.0101 & 3.0769 & 0.007346 & 0.9702 & 168 & 4 & 23.5 \\
\hline Oblada melanura & 0.0247 & 2.781 & 0.005207 & 0.996 & 7 & 8.5 & 21 \\
\hline Ophiodon barbatum & 0.0036 & 3.1103 & 0.005503 & 0.984 & 45 & 7.5 & 22 \\
\hline Oxyurichthys petersi* & 0.0206 & 2.5365 & 0.012296 & 0.8528 & 26 & 11 & 22 \\
\hline Pagellus acarne & 0.0055 & 3.3254 & 0.003376 & 0.9753 & 311 & 5 & 16.5 \\
\hline Pagellus bogaraveo & 0.0188 & 2.9314 & 0.009847 & 0.9679 & 18 & 7 & 14.5 \\
\hline Pagellus erythrinus & 0.0127 & 3.0257 & 0.005696 & 0.9873 & 143 & 4 & 24 \\
\hline Pagrus coeruleostictus & 0.033 & 2.7504 & 0.008504 & 0.9935 & 37 & 6.5 & 44 \\
\hline Plotosus lineatus* & 0.0034 & 3.2537 & 0.00794 & 0.9669 & 161 & 5 & 23 \\
\hline Pomadasys incisus & 0.0095 & 3.1274 & 0.004264 & 0.9929 & 19 & 11 & 22.5 \\
\hline Pomadasys stridens* & 0.0107 & 3.0889 & 0.01148 & 0.9485 & 10 & 9 & 14.5 \\
\hline Pteragogus pelycus* & 0.015 & 2.929 & 0.007997 & 0.9782 & 14 & 6 & 10 \\
\hline Sardina pilchardus & 0.0039 & 3.2882 & 0.003769 & 0.9672 & 261 & 6 & 21 \\
\hline Sardinella aurita & 0.0025 & 2.6422 & 0.003634 & 0.9306 & 95 & 9 & 24 \\
\hline Sardinella maderensis & 0.0112 & 2.9211 & 0.054406 & 0.9882 & 15 & 13.5 & 25.5 \\
\hline Sargocentron rubrum* & 0.0214 & 2.938 & 0.005881 & 0.9635 & 35 & 11 & 23.5 \\
\hline Saurida undosquamis* & 0.0039 & 3.1538 & 0.006612 & 0.9918 & 84 & 6 & 36 \\
\hline Scomber colias & 0.0034 & 3.291 & 0.004591 & 0.9845 & 130 & 6.5 & 30.5 \\
\hline Scomberomorus commerson* & 0.0113 & 2.8494 & 0.00593 & 0.9807 & 17 & 21.5 & 51.5 \\
\hline Scorpaena elongata & 0.0146 & 3.0657 & 0.004879 & 0.999 & 8 & 7 & 24 \\
\hline Scorpaena notata & 0.0258 & 2.855 & 0.014324 & 0.9737 & 12 & 6.5 & 12 \\
\hline Scorpaena porcus & 0.0097 & 2.8389 & 0.013651 & 0.9918 & 5 & 10 & 21.5 \\
\hline Scorpaena scrofa & 0.013 & 3.128 & 0.006939 & 0.9983 & 8 & 7 & 19.5 \\
\hline Seriola dumerili & 0.0085 & 3.1225 & 0.006135 & 0.9726 & 23 & 21 & 39.5 \\
\hline Serranus cabrilla & 0.0095 & 3.0729 & 0.009257 & 0.9845 & 36 & 6.3 & 22 \\
\hline Serranus hepatus & 0.0118 & 3.159 & 0.007568 & 0.9656 & 97 & 4.5 & 10 \\
\hline Siganus rivulatus* & 0.0145 & 2.8942 & 0.014034 & 0.9526 & 36 & 8.5 & 23.5 \\
\hline Sillago suezensis* & 0.0063 & 3.0762 & 0.004672 & 0.9813 & 34 & 8.5 & 18.5 \\
\hline Solea solea & 0.0721 & 2.3086 & 0.052164 & 0.9068 & 4 & 14.5 & 17.5 \\
\hline Sphoeroides pachygaster & 0.0866 & 2.5455 & 0.018968 & 0.9412 & 9 & 12 & 26 \\
\hline Sphyraena chrysotaenia* & 0.0089 & 2.8528 & 0.004931 & 0.9384 & 92 & 9.5 & 32 \\
\hline Sphyraena sphyraena & 0.004 & 3.0077 & 0.009013 & 0.985 & 36 & 9.5 & 40 \\
\hline Spicara flexuosa & 0.0103 & 3.0631 & 0.004677 & 0.9788 & 43 & 7.5 & 17.2 \\
\hline Spicara maena & 0.0116 & 2.9541 & 0.004478 & 0.8523 & 209 & 8 & 17 \\
\hline Spicara smaris & 0.0149 & 2.8043 & 0.004775 & 0.9387 & 232 & 5 & 15 \\
\hline Stephanolepis diaspros* & 0.0164 & 3.0335 & 0.010481 & 0.9796 & 64 & 4 & 20.5 \\
\hline Synodus saurus & 0.0112 & 2.8802 & 0.007566 & 0.9618 & 34 & 10 & 24 \\
\hline Torquigener flavimaculosus* & 0.104 & 2.2155 & 0.022454 & 0.932 & 10 & 5.5 & 10.5 \\
\hline Trachinus draco & 0.0018 & 3.4875 & 0.007315 & 0.9877 & 15 & 14 & 26 \\
\hline Trachurus indicus* & 0.009 & 2.9372 & 0.004468 & 0.9798 & 205 & 6.5 & 12 \\
\hline Trachurus mediterraneus & 0.0088 & 3.0041 & 0.010208 & 0.9808 & 47 & 7 & 24.5 \\
\hline Trachurus trachurus & 0.0109 & 2.8978 & 0.004754 & 0.9885 & 103 & 5.5 & 29.5 \\
\hline Trichiurus lepturus & 0.0029 & 2.5504 & 0.01876 & 0.895 & 20 & 16 & 44 \\
\hline Trigloporus lastoviza & 0.0115 & 3.0112 & 0.006095 & 0.9834 & 45 & 8 & 23 \\
\hline Upeneus moluccensis* & 0.0085 & 3.1033 & 0.004528 & 0.9538 & 162 & 6 & 20.5 \\
\hline Upeneus pori* & 0.005 & 3.3081 & 0.006462 & 0.9773 & 68 & 7 & 17.5 \\
\hline Uranoscopus scaber & 0.0123 & 3.1094 & 0.007136 & 0.9826 & 29 & 9.5 & 23.5 \\
\hline Xyrichthys novacula & 0.0034 & 3.4817 & 0.014933 & 0.9656 & 7 & 11.5 & 19 \\
\hline Zeus faber & 0.0029 & 2.7431 & 0.020001 & 0.9905 & 21 & 4.5 & 47 \\
\hline
\end{tabular}

